\title{
Gonadotropin Releasing Hormone Measurement
}

National Cancer Institute

\section{Source}

National Cancer Institute. Gonadotropin Releasing Hormone Measurement. NCI

Thesaurus. Code C74860.

The determination of the amount of gonadotropin releasing hormone present in a sample. 